\title{
IMPLEMENTASI MONITORING PENYALURAN PROGRAM RASKIN DI DESA PAULAN COLOMADU KABUPATEN KARANGANYAR
}

\author{
Liliek Winarni \\ Damayanti Suhita
}

\begin{abstract}
Abstrak
Dalam pelaksanaan program beras miskin (raskin) bagi keluarga miskin menunjukkan hasil monitoring bahwa realitasnya faktor kerjasama antara petugas aparat dan tokoh masyarakat yang mendapatkan tugas membantu pelaksanaan distribusi sangat penting dan cukup efektif meskipun ada beberapa dari warga masyarakat masih ada yang kurang partisipatif. Sedangkan manfaat untuk masyarakat penerima raskin dapat dijelaskan bahwa menunjukkan warga cukup sejahtera melalui perwujudan ketersediaan pangan yang cukup bermutu, bergizi dan tersebar merata di wilayah desa Paulan serta terjangkau oleh daya beli masyarakat.

Kata-kata Kunci : Implementasi monitoring distribusi, Faktor Lingkungsn, Manfaat bagi Warga.
\end{abstract}

\begin{abstract}
In the implementation of the poor rice program (raskin) for poor families, the results of monitoring show that the reality of the collaboration factor between officials and community leaders who have the task of assisting the distribution is very important and quite effective even though there are some members of the community who are still less participatory. While the benefits for the recipient community of Raskin can be explained that it shows that the community is quite prosperous through the realization of sufficient quality, nutritious and evenly distributed food in the Paulan village area and affordable by the people's purchasing power.

Keywords: Implementation of distribution monitoring, Environmental Factors, Benefits for Residents
\end{abstract}

\section{Pendahuluan}

Dalam upaya penanggulangan kemiskinan ada dua strategi utama yang harus ditempuh oleh pemerintah. Pertama, melindungi keluarga dan kelompok masyarakat miskin melalui pemenuhan kebutuhan pokok mereka. Kedua, memberdayakan mereka agar mempunyai kemampuan untuk melakukan usaha dan mencegah terjadinya kemiskinan baru.

Sejak tahun 2002, subsidi pangan untuk keluarga miskin diteruskan melalui Program Raskin. Penggantian nama program ini dilakukan semata-mata untuk mempertajam tingkat keberhasilan program dimaksud agar lebih tepat sasaran kepada keluarga miskin. Untuk meningkatkan keakuratan data rumah tangga sasaran, pemerintah memperbaharui basis data melalui Pendataan Program Perlindungan Sosial (PPLS) yang dilakukan oleh Badan Pusat Statistik.

Dengan penetapan basis data terpadu, Tim Nasional Percepatan Penanggulangan Kemiskinan (TNP2K) akan menetapkan RTS-PM berdasarkan informasi yang lebih 
akurat. Sedangkan untuk melakukan penyediaan beras, pemerintah menunjuk Perum Bulog sebagai agen tunggal dalam penyaluran beras hingga ke titik distribusi (Mendagri 2003). Program semacam ini sebenarnya sudah ada sejak krisis pangan di Indonesia pada tahun 1998 yang dinamakan dengan Operasi Pasar Khusus (OPK). Namun, baru pada tahun 2002 program OPK ini diubah namanya menjadi program beras untuk Rumah Tangga Miskin (Raskin) dan pada tahun 2008 menjadi beras bersubsidi untuk masyarakat berpendapatan rendah (Raskin).

Program ini bertujuan untuk mengurangi beban pengeluaran rumah tangga sasaran melalui pemenuhan sebagian kebutuhan pokok dalam bentuk beras.

Pada saat ini, di daerah kelurahan Paulan, Colomadu sedang ramai - ramai yang membicarakan tentang program beras miskin yang disebut Raskin, kebetulan peneliti sebagai anggota ibu PKK yang membantu mendistribusikan beras dari pemerintah kepada warga yang berhak menerimanya, oleh karena itu peneliti tertarik untuk mengangkat tema ini sebagai salah satutopik yang akan dibahas dalam penelitian ini.

Raskin merupakan subsidi pangan pokok dalam bentuk beras yang diperuntukkan bagi keluarga miskin sebagai upaya dari pemerintah untuk meningkatkan ketahanan pangan dan memberikan perlindungan pada keluarga miskin. Beras merupakan makanan pokok sebagian besar penduduk Indonesia. Oleh karena itu, pada tahun 2017/2018 pemerintah Indonesia meluncurkan program raskin yang merupakan implementasi dari konsistensi pemerintah dalam rangka memenuhi hak pangan masyarakat.

Selain itu, raskin bertujuan untuk meningkatkan dan membuka akses pangan keluarga melalui penjualan beras kepada keluarga penerima manfaat dengan jumlah yang telah ditentukan. Keluarga penerima manfaat raskin yaitu keluarga yang berpendapatan rendah (miskin dan rentan miskin) atau disebut dengan Rumah Tangga Sasaran Penerima Manfaat (RTS-PM). RTS-PM Raskin ditetapkan berdasarkan Pendataan Program Perlindungan Sosial (PPLS2011) oleh Badan Pusat Statistik (BPS).

Raskin merupakan salah satu dari berbagai program-program pro rakyat yang diluncurkan oleh pemerintah Indonesia sebagai upaya percepatan penanggulangan kemiskinan. Hal ini telah diatur dalam Peraturan Presiden Republik Indonesia Nomor 15 Tahun 2010 tentang 
Percepatan

Penanggulangan

Kemiskinan dan Instruksi Presiden

Nomor 3 Tahun 2010 tentang Program

Pembangunan yang berkeadilan.

Berdasarkan Surat Kementerian

Koordinator Kesejahteraan Rakyat No.

B-2143/KMK/Dep.II/XI/2007, salah satu alternatif tindakan yang dilakukan pemerintah dalam menanggulangi kemiskinan ini diwujudkan dalam kebijakan beras untuk keluarga miskin sebagai tindaklanjut pendistribusian beras bersubsidi dengan ketentuan setiap rumah tangga memperoleh 10 $\mathrm{Kg}$ hingga $15 \mathrm{Kg}$.

Tetapi program raskin ini tidak berjalan seperti yang diharapkan. Banyak kendala dan penyimpangan yang terjadi, baik dari pusat maupun di daerah. Mekanisme pembagian Raskin di Kalurahan Paulan Kecamatan Colomadu Kabupaten Karanganyar dimulai dengan pengiriman beras yang berasal dari Perum Bulog ke balai Desa Paulan lalu disalurkan ke masingmasing RT. Melalui ketua setiap RT, beras Raskin tersebut disalurkan kepada warga.

Namun, beras yang diterima oleh masyarakat miskin di Desa Paulan tersebut tidak sesuai dengan jumlah yang telah ditentukan yaitu rata-rata menyusut menjadi $2,5 \quad-4$ $\mathrm{Kg} / \mathrm{RTS} /$ bulan dengan harga tebus sebesar Rp 1.600,00/Kg di titik distribusi dan rata-rata $\mathrm{Rp} 2.000,00 / \mathrm{Kg}$ di titik bagi. Hal ini disebabkan karena Raskin didistribusikan dengan kebijakan bagi rata sehingga Raskin juga dinikmati oleh masyarakat yang tidak miskin yang akhirnya menyebabkan hak yang diterima oleh masyarakat yang miskin menjadi berkurang.

Dari beberapa penelitian menunjukkan adanya penyimpangan dalam pendistribusian beras sehingga menyebabkan sekitar 18\% raskin tidak sampai ke tangan orang miskin. Laporan penelitian lain menemukan berbagai permasalahan dalam implementasi program raskin di tataran pelaksanaan (Hastuti and Maxwell 2003; Sulaksono and Mawardi 2012).

Problem pemberian beras raskin yang tidak tepat sasaran ini rupanya juga terjadi di banyak wilayah, sebagian kecil terjadi di kalurahan Paulan, Colomadu, Kabupaten Karanganyar. Bahkan ada yang lebih parah, berasnya tidak sampai kepada warga tapi malah dijual kepada penadah oleh penyalur raskinnya. Ada pula kasus beras yang ditukar dengan kualitas yang lebih jelek ini sering terjadi. Pokok persoalannya bisa jadi penanggung jawab raskin ikut serta andil dalam ketidaktepatan sasaran program ini. 
Fungsi Monitoring mnerupakan satu diantara tiga komponen penting lainnya dalam system manajelemen program, yaitu Perencanaan, Pelaksanaan dan Tindakan korektif (melalui umpan balik). Sebagai siklus, dia berlangsung secara intens ke arah pencapaian target-target antara dan akhirnya tujuan program. ( Mercurius Broto Legowo - 12 Oktober 2016). Menurut Dunn (1981), monitoring mempunyai tempat fungsi, yaitu: Ketaatan (compliance).

Monitoring menentukan apakah tindakan administrator, staf, dan semua yang terlibat mengikuti standar dan prosedur yang telah ditetapkan.Pemeriksaan (auditing). Monitoring menetapkan apakah sumber dan layanan yang diperuntukkan bagipihak tertentu (target) telah mencapai mereka. Monitoring menghasilkan ninformasi yang membantu "menghitung" hasil perubahan sosial dan masyaraka tsebagai akibat implementasi kebijaksanaan sesudah periode waktu tertentu.

Meter dan Horn dalam Subarsono (2009 : 35) mengatakan, bahwa yang menentukan keberhasilan implementasi kebijakan antara lain :

a. Standar dan Tujuan Kebijakan (Policy standars objecties), standar dan tujuan kebijakan memberikan perhatian utama pada faktor-faktor yang menentukan hasil kerja, maka identifikasi indikator-indikator hasil kerja merupakan hal yang penting dalam analisis. Karena indikator ini menilai, sejauh mana standar dan tujuan menjelaskan keseluruhan kebijakan, ini terbukti karena mudah diukur dalam berbagai kasus.

b. Sumberdaya Kebijakan (Policy Resources) Implementasi kebijakan bukan hanya pada standar dantujuan, tetapi juga menyediakan sumberdaya yang digunakan untuk memudahkan administrasi. Sumberdaya yang dimaksudkan meliputidana dan insentifyang diharapkan dapat menunjang implementasiyang efektif.

\section{Metode Penelitian}

Jenis penelitian, peneliti menggunakan jenis penelitian analisis kualitatif deskriptif yaitu penelitian yang digunakan untuk menganalisis data dengan cara mendeskripsikan data yang telah diteliti. Untuk itu peneliti berusaha memaparkan dan bertujuan untuk memberikan gambaran serta penjelasan dari variabel yang diteliti, Penelitian kualitatif deskriptif merupakan penelitian yang dimaksudkan untuk mengumpulkan informasi mengenai status variabel, gejala, atau keadaan yang ada, yaitu keadaan gejala menurut apa adanya pada saat penelitian dilakukan. 
Menurut Sugiyono (2009:96), pemilihan informan dilakukan dengan menggunakan teknik purposive sampling dan aksidental sampling. Purposive.Sampling yaitu teknik pengambilan sampel sumber data dengan pertimbangan tertentu. Informan tersebut yang dianggap paling mengerti tentang apa yang harapkan oleh peneliti, atau mungkin dia sebagai penguasa sehingga akan memudahkan peneliti menjelajahi objek atau situasi sosial yang diteliti. Dalam teknik ini yang dipandang sebagai key informan, yaitu Kepala Kalurahan Paulan dan informan lainnya adalah : Pegawai atau staf kantor Kalurahan Paulan serta Ketua RT dan masyarakat yang menerima raskin.

Sedangkan aksidental sampling yaitu teknik pengambilan sampel sumber data berdasarkan kebetulan atau siapa saja yang secara kebetulan bertemu dengan peneliti dapat dijadikan sumber data, seperti dalam teknik ini informannya yaitu masyarakat.

: $\quad$ Teknik pengumpulan data dilakukan dengan cara observasi, wawancara dan melakukan studi dokumentasi dengan jumlah narasumber 9 orang (Hamidi: 2010). Analisis data dalam penelitian ini adalah dengan model interaktif. Dalam analisis interaktif, data yang telah terkumpul dibaca, dipelajari dan ditelaah, kemudian dilakukan pembuatan abstraksi, kemudian data disusun dalam satuan-satuan sambil dilakukan pemeriksaan keabsahan data. Tahap akhir yang dilakukan adalah penafsiran data. Karena peneliti menggunakan metode penelitian kualitatif, maka jenis data yang digunakan dalam penelitian ini meliputi teks atau tulisan, kata-kata tertulis, informasi yang terkait.

Analisis data yang digunakan dalam penelitian ini adalah analisis data kualitatif menurut Miles dan Huberman (Satori dan Komariah, 2010:39) menggunakan analisis data model interaktif yang terdiri dari empat komponen yaitu terdiri dari tahap pengumpulan data, reduksi data, penyajian data penarikan kesimpulan atau verifikasi.

\section{Hasil Penelitian dan Pembahasan}

Program Beras untuk Keluarga Miskin (Raskin) adalah program pemerintah yang menganggarkan subsidi pangan melalui pendistribusian beras kepada keluarga miskin, dimana masing - masing keluarga akan menerima beras minimal $15 \mathrm{~kg} / \mathrm{KK}$ per bulan Netto. Dengan demikian pengelola program raskin Desa Paulan sudah mengetahui sasaran dan tujuan program raskin. Pelaksanaan Program 
Raskin di Desa Paulan Colomadu, pelaksanaannya berjalan dengan baik dan sudah sesuai dengan ketentuan yang telah ditetapkan oleh Pemerintah. Pengelola Program Raskin Desa

Dalam menyampaikan program raskin, petugas raskin Desa Paulan sekaligus sebagai monitoring yang telah mendapatkan pelatihan di tingkat kecamatan dan mensosialisasikan program di tingkat desa, RW dan RT serta pada pertemuan-pertemuan yang dihadiri oleh warga Desa Paulan. Pengelola Program Raskin Desa Paulan sudah mendapatkan pembekalan dalam mengelola program tersebut.

Tahapan yang dilakukan oleh petugas raskin Desa Paulan antara lain setelah mendapatkan Raskin dari petugas tingkat Kecamatan (Kasi Kesos) disalurkan ke RW dengan dasar data yang sudah ditentukan sebelumnya. Kemudian dari RW disalurkan ke RT. Setelah itu Rumah Tangga Sasaran mengambil Raskin di masing-masing RT. Dengan demikian Pengelola Program Raskin Desa Paulan dalam menyalurkakn Raskin sudah sesuai dengan tahapan yang telah ditentukan sebelumnya oleh pemerintah.

Kendala yang dihadapi dalam program raskin antara lain masih banyaknya masyarakat miskin yang belum tersentuh bantuan program raskin tersebut. Disamping itu, kurang akuratnya data mengenai siapa dan di mana masyarakat yang

sangat terkena dampak krisis (masyarakat miskin). Adanya kehendak masyarakat yang menginginkan beras raskin dibagi rata. Pengelola program raskin Desa Paulan berhasil mendistribusikan beras miskin sesuai dengan ketentuan yang ada walaupun ada tantangan dari masyarakat yang ingin agar raskin dapat dibagi rata. Hanya saja permasalahan yang dihadapi dilapangan adalah kurangnya jatah raskin yang diterima oleh warga miskin dalam hal ini dikarenakan jumlah warga miskin masih banyak yang belum bisa menikmati program raskin tersebut.

Dari hasil penelitian dapat dilihat bahwa tujuan program raskin ini tercapai meski dalam kenyataannya jumlah beras yang diterima tidak sesuai dengan ketentuan. Sedangkan dilihat dari sasaran, sasaran program raskin di Desa Paulan ini adalah masyarakat atau keluarga yang dikategorikan sebagai masyarakat yang miskin yang telah ditetapkan sebagai Rumah Tangga Sasaran Penerima Manfaat (RTS-PM). Berdasarkan penelitian diketahui bahwa dalam pendistribusian raskin ke sasaran, dikenal dengan istilah bagi 
roto, dalam arti pembagian raskin ini tidak lagi sesuai dengan sasaran yang telah di tetapkan melainkan sesuai dengan kesepakatan yang telah dibuat oleh lingkungan RT masing-masing. Berdasarkan temuan yang ada, dapat dikatakan program ini tidak memenuhi unsur sasaran, dengan tidak tepatnya sasaran dalam implementasi program raskin meski telah ditetapkan dalam peraturan.

Dalam menghapi kendala penyaluran program raskin Pemerintah Desa Paulan dan petugas raskin memberikan pengertian - pengertian terhadap warga agar menyadari bahwa setiap program yang diberikan pemerintah tentu masih ada kelemahan-kelemahan atau kekurangan, program raskin diberikan kepada masyarakat yang benar-benar tidak mampu dalam memenuhi kebutuhan sehari -hari.

Petugas raskin selalu monitoring data penerima raskin hal ini dilakukan untuk mengetahui apabila ada perubahan penerima program raskin petugas raskin segera merubah data penerima program tersebut. Pengelola Raskin Desa Paulan sudah memberikan penjelasan - penjelasan agar penerima raskin adalah benarbenar warga miskin sesuai dengan kriteria yang telah ditentukan oleh pemerintah. Desa Paulan dalam penyaluran program raskin sudah sesuai dengan juklak dan juknis yang ditetapkan Pemerintah. Dengan demikian pengelola program raskin Desa Paulan dapat dikatakan bekerja sesuai dengan ketentuan yang telah ditentukan.

Disisi lain, petugas raskin selalu dipantau oleh tokoh - tokoh masyarakat, serta masyarakat penerima program raskin diberikan keleluasaan untuk memberi masukan agar program berjalan sesuai prosedur yang ditetapkan. Pengelola Program

Raskin Desa Paulan juga menerima saran dan masukan dari berbagai pihak untuk kelancaran program raskin didesa Paulan.

Menurut Dunn (2003), monitoring mempunya empat fungsi, yaitu:

a. Ketaatan (compliance). Monitoring menentukan apakah tindakan administrator, staf, dan semua yang terlibat mengikuti standar dan prosedur yang telah ditetapkan.

b. Pemeriksaan (auditing). Monitoring menetapkan apakah sumber dan layanan yang diperuntukkan bagi pihak tertentu bagi pihak tertentu (target) telah mencapai mereka.

c. Laporan (accounting). Monitoring menghasilkan informasi yang membantu "menghitung" hasil perubahan sosial dan masyarakat 
sebagai akibat implementasi kebijaksanaan sesudah periode waktu tertentu.

d. Penjelasan (explanation). Monitoring menghasilkan informasi yang membantu menjelaskan bagaimana akibat kebijaksanaan dan mengapa antara perencanaan dan pelaksanaannya tidak cocok.

Selajutnya, dalam rangka pelaksanaan program raskin dan untuk mengefektifkan pelaksanaan program dan pertanggungjawabannya, maka dibentuk petugas raskin baik di tingkat kabupaten, kecamatan dan di tingkat kelurahan. Penanggung jawab program raskin di Kabupaten Karanganyar adalah Bupati, di kecamatan adalah Camat, dan di kelurahan adalah Kepala Desa. Berdasarkan hasil penelitian, segi penanggung jawab dapat dilihat bahwa dari tugas dan fungsi petugas masih memiliki tugas yang belum maksimal yaitu berkaitan dengan sosialisasi.

Sosialisasi program raskin masih belum menyentuh kepada masyarakat. Masyarakat masih belum jelas mengenai harga tebus beras yang sebenarnya, masyarakat hanya mengetahui besaran uang yang harus dibayar untuk mendapatkan beras raskin. Kemudian mengenai pengaduan, peneliti berpendapat bahwa selama ini masyarakat masih menerima dengan apa adanya beras raskin ini meski dengan kualitas yang jelek dan tidak mengertinya mengenai prosedur pengaduan. Masalah sosialisasi yang berkaitan dengan prosedur pengaduan harus benar-benar dilaksanakan oleh penanggung jawab dari masing-masing tingkat, terutama di tingkat desa.

Selain itu dalam implementasi program raskin petugas juga mempunyai fungsi untuk mengawasi pelaksanaan program, berdasarkan hasil penelitian dapat dilihat bahwa dari segi pengawasan dapat dibagi menjadi tiga tingkatan pengawasan yakni pengawasan ditingkat atas, yang dimaksud adalah pengawasan yang dilakukan oleh pihak Perum Bulog, Bidang Administrasi Perekonomian serta petugas raskin. Kemudian pengawasan yang dilakukan oleh pegawai desa atau pelaksana distribusi desa yang betugas mengawasi di titik distribusi mengenai jumlah beras raskin yang diterima sesuai dengan ketentuan yang telah ditetapkan.

Kemudian pengawasan yang dilakukan oleh pelaksana distribusi desa yang mengawasi penyaluran raskin sampai pada titik bagi sesuai dengan jatah atau kuota masing-masing RT. Menunjuk pada Pedoman Umum Raskin, untuk pengawasan masih 
belum dijelaskan secara jelas mengenai pengawasan.

Dilihat dari pemanfaatan, seperti yang telah ditetapkan sebagaimana tertuang dalam petunjuk teknis program raskin, program ini diharapkan :

a) meningkatkan ketahanan pangan di tingkat rumah tangga sasaran, sekaligus mekanisme perlindungan sosial dan penanggulangan kemiskinan. b) peningkatan akses pangan yang baik secara fisik maupun ekonomi kepada RTS. c) sebagai pasar bagi hasil usaha tani padi. d) stabilisasi harga beras dipasaran. e) pengendalian inflasi dengan penetapan harga beras rata-rata $\mathrm{Rp} .2 .000,-/ \mathrm{kg}$.

Berdasaran hasil penelitian serta wawancara dengan beberapa warga, dapat diketahui bahwa masyarakat sangat merasakan manfaat dari adanya program raskin ini yang dapat mengurangi beban pengeluaran serta memenuhi kebutuhan pangan beras masyarakat namun seperti yang disampaikan beberapa masyarakat yang menyatakan bahwa beras raskin hanya cukup untuk kebutuhan sekitar satu minggu saja. meski sangat merasakan akan manfaat dari program namun hal tersebut belum memenuhi kriteria yang menjadi bagian penting mengenai manfaat program raskin sebagaimana yang telah dipaparkan.
Hal tersebut tidak terlepas dari pemerataan pembagian beras raskin yang di bagi rata kepada seluruh warga baik yang tergolong masyarakat miskin dan yang kaya. Mestinya jatah beras yang diterima sasaran untuk ketahanan pangan selama satu bulan terpangkas dengan hanya cukup untuk satu minggu. Kemudian pokok pemanfaatan melalui peningkatan akses yang baik secara fisik juga belum bisa untuk dicapai. Terlihat dengan kualitas beras raskin yang diterima oleh masyarakat.

Beras memang tersedia pada titik distribusi namun dengan kualitas yang jelek maka sampai berikut ini juga belum bisa dicapai. Kualitas beras juga menjadi persoalan yang terus menjadi sorotan yakni kualitas beras raskin yang jelek. Kemudian manfaat untuk pasar bagi hasil usaha tani, dalam hal ini yakni proses pembelian hasil pertanian terutama adalah gabah. Proses pengadaan beras memang telah ditentukan sesuai dengan Inpres No 5 Tahun 2015 dengan kriteria-kriteria yang telah ada. Namun untuk harga beli sesuai dengan ketentuan tersebut belum bisa dapat digunakan kembali untuk membeli beras dengan kualitas yang layak.

Sementara dengan adanya program beras raskin ini diharapkan harga beras menjadi stabil, namun 
dalam bulan-bulan tertentu harga beras dapat menjadi tidak stabil, misalkan pada bulan puasa dan lainnya. Masyarakat tidak dapat bergantung pada jatah beras raskin yang diterima itu pun dengan jumlah yang tidak sesuai. Perhatian khusus dari pemerintah memang diperlukan untuk menambah jumlah beras atau pun menyiasati berkaitan dengan stabilisasi harga beras tersebut.

Kemudian bagian terakhir yang menjadi pedoman analisis manfaat yakni program raskin ini menjadi salah satu pengendalian inflasi dengan intervensi pemerintah dalam penetapan harga beras yaitu sebesar Rp 2.000,$/ \mathrm{kg}$. Namun yang terjadi di lapangan, harga tebus beras menjadi bertambah dengan adanya pungutan lain yang dikenakan kepada masyarakat yakni biaya angkut atau biaya transportasi. Hasil yang terjadi di lapangan ini membuktikan bahwa dalam segi pemanfaatan, dilihat berdasarkan keadaan di lokasi penelitian yang tercantum dalam Pedoman Umum dan menjadi kriteria pembahasan diketahui bahwa sasaran utama tersebut belum mencapai target pemanfaatan dalam program beras raskin ini.

Kegiatan rutin yang dilakukan oleh petugas raskin dalam Implementasi Monitoring Penyaluran Program Raskin Di Desa Pauluan
Colomadu menunjukkan, bahwa pelaksanaaan distribusi beras raskin menurut data yang diperoleh proses dalam penerimanya raskin hanya diberikan kepada keluarga yang benarbenar tidak mampu. Beras miskin ini dibagikan berdasarkan hasil musyawarah dari para tokoh masyarakat dengan perangkat desa Paulan dan inti materi bahasannya yaitu untuk menentukan siapa yang berhak untuk menerima raskin, disisi lain pelaksanaan distribusi dilakukan dalam pembagiannya kepada masyarakat dengan kategori kelompok miskin dengan mempettimbangkan faktor situasi kondisi lingkungan sehingga telah disepakati bahwa pemberian beras raskin dilakukan secara bergantian sesuai daftar yang telah ditentukan.

Beras yang diterima oleh masyarakat tentang jenis dan mutunya beras itu sendiri sama artinya tidak ada yang diprioritaskan, maksudnya dengan beras yang agak bagus dan masih layak untuk dikonsumsi oleh masyarakat. Dalam pelaksanaan program beras miskin (raskin) bagi keluarga miskin dapat didiskripsikan bahwa faktor kerjasama antara petugas aparat dan tokoh masyarakat yang mendapatkan tugas membantu pelaksanaan distribusi sangat penting dan cukup efektif meskipun ada 
beberapa dari warga masyarakat masih ada yang kurang partisipatif.

Sedangkan manfaat untuk masyarakat penerima raskin dapat dijelaskan bahwa menujukkan warga cukup sejahtera melalui perwujudan ketersediaan pangan yang cukup bermutu, bergizi dan tersebar merata di wilayah desa Paulan serta terjangkau oleh daya beli masyarakat.

\section{Penutup}

Dari hasil pembahasan serta berbagai faktor-faktor yang mendukung maupun yang menghambat pelaksanaan program raskin yang telah dipaparkan. Sehingga peneliti memberikan kesimpulan bahwa program raskin yang dilaksanakan di Desa Paulan Kecamatan Colomadu Kabupaten Karanganyar, tidak berjalan dengan baik karena masih terdapat warga yang kurang partisipasif. Adapun saran yang dapat diberikan peneliti yang berkaitan dengan kesimpulan yang telah dipaparkan serta untuk membangun Program Raskin yang lebih baik kedepannya, yaitu berkaitan dengan pengkajian ulang kesiapan program, sosialisasi yang lebih intens kepada masyarakat, update data minimal 2 tahun sekali serta penghapusan sistem bagi rata terhadap pembagian raskin.

\section{Daftar Pustaka}

Moleong, Lexy J, 2004. Metode Penelitian Kualitatif, PT Remaja Rosdakarya,Bandung.

Hamidi, 2010, Metode Penelitian dan Teori Komunikasi, UMM Press, Malang

Hastuti, B. Sulaksono and S. Mawardi. 2012. Tinjauan Efektivitas Pelaksanaan Raskin dalam Mencapai Enam Tepat. Jakarta: Smeru Research Institute.

Hastuti, S. Usman, B. Sulaksono and R. J. Sodo. 2011. Kajian cepat terhadapPendataan Program Perlindungan Sosial (PPLS) 2011. Jakarta: TNP2K.

Mendagri. 2003. Pelaksanaan Program Beras untuk Keluarga Miskin.

Subarsono, 2009. Analisis Kebijakan Publik (Konsep, Teori dan Aplikasi), Pustaka Pelajar, Yogyakarta.

Sugiyono, 2009. Metode Penelitian Kualitatif, Kuantitatif dan R\&D, Alfabeta, Bandung.

Satori, Djam'an dan Aan Komariah, 2010. Metodologi Penelitian Kualitatif, Alfabeta, Bandung.

William N Dunn , (2003), Pengantar Analisis Kebijakan Publik (terjemahan),Yogyakarta, Gajahmada University press 